\title{
Greenland Ice Sheet Surface Mass Loss: Recent Developments in Observation and Modeling
}

\author{
Michiel van den Broeke ${ }^{1}$ (D) Jason Box ${ }^{2}$. Xavier Fettweis ${ }^{3} \cdot$ Edward Hanna $^{4}$. \\ Brice Noël ${ }^{1} \cdot$ Marco Tedesco $^{5}$ - Dirk van As $^{2}$ - Willem Jan van de Berg ${ }^{1}$. \\ Leo van Kampenhout ${ }^{1}$
}

Published online: 7 November 2017

(C) The Author(s) 2017. This article is an open access publication

\begin{abstract}
Surface processes currently dominate Greenland ice sheet (GrIS) mass loss. We review recent developments in the observation and modeling of GrIS surface mass balance (SMB), published after the July 2012 deadline for the Fifth Assessment Report of the Intergovernmental Panel on Climate Change (IPCC AR5). Since IPCC AR5, our understanding of GrIS SMB has further improved, but new observational and model studies have also revealed that temporal and spatial variability of many processes are still poorly quantified and understood, e.g., bio-albedo, the formation of ice lenses and their impact on lateral meltwater transport, heterogeneous vertical meltwater transport ('piping'), the impact of atmospheric-circulation changes and mixed-phase clouds on the surface energy balance, and the magnitude of turbulent heat exchange over rough ice surfaces. As a result, these processes are only schematically or not at all included in models that are currently used to assess and predict future GrIS surface mass loss.
\end{abstract}

This article is part of the Topical Collection on Glaciology and Climate Change

Michiel van den Broeke

m.r.vandenbroeke@uu.nl

1 Institute for Marine and Atmospheric Research Utrecht, Utrecht University, Utrecht, The Netherlands

2 Geological Survey of Denmark and Greenland, Copenhagen, Denmark

3 Department of Geography, University of Liège, Liège, Belgium

4 School of Geography and Centre for Water \& Planetary Health, University of Lincoln, Lincoln, UK

5 Lamont-Doherty Earth Observatory, Columbia University, New York, USA
Keywords Greenland ice sheet · surface mass balance . observations $\cdot$ modelling

\section{Introduction}

In the Fifth Assessment Report (AR5) of the Intergovernmental Panel on Climate Change [51], mass loss from the Greenland ice sheet (GrIS) is discussed in chapter 4 on observed changes in the cryosphere [108] and chapter 13 on sea level change [13]. In these chapters, results published prior to July 2012 are combined to demonstrate that the GrIS (including its peripheral glaciers) lost an estimated $2.9 \pm 0.5 \times 10^{3} \mathrm{Gt}$ of mass between 1991 and 2011, equivalent to $\approx 8 \mathrm{~mm}$ of global mean sea level rise (SLR). Importantly, the annual mass loss rate averaged over the decade 2002-2011 (214 $\left.\pm 58 \mathrm{Gt}_{\text {year }}^{-1}\right)$ represented a 6fold increase over the preceding decade, followed by a peak mass loss in 2012 and more moderate losses afterwards, averaging around $200 \mathrm{Gt} \mathrm{year}^{-1}$ [97]. The conclusion in IPCC AR5 that surface mass loss from the GrIS had become the largest single source of SLR and is likely to remain so for decades to come, has significantly intensified scientific research in this field. In this paper, we aim to provide a concise (and therefore not necessarily complete) summary of post-IPCC AR5 research on this topic, including results from models and remotelysensed/in situ observations. After providing some essential SMB definitions in the next section, the remaining sections briefly discuss recent developments and outstanding questions in each of the following topics:

- Mass loss partitioning, quantifying the relative importance of surface processes compared to ice dynamics (ice flow over the grounding line and subsequent basal melt or iceberg calving) for recent GrIS mass loss 
- The collection of in situ SMB data, a requirement to evaluate and validate SMB models and remotely sensed data, respectively, and assess their uncertainties

- Historical (twentieth century) SMB reconstructions, to put the recent surface mass losses from the GrIS in a historical perspective and assess the role of natural climate variability

- The impact of large-scale atmospheric circulation variability, specifically the North-Atlantic Oscillation (NAO), on recent GrIS surface mass loss and whether recent changes therein are of natural or anthropogenic origin

- Clouds, radiation, and turbulence, describing how the large-scale atmospheric circulation impacts surface melt through clouds, inducing melt at the higher elevations of the ice sheet, and turbulent sensible heat exchange, important for high melt rates of the rough summer ice surface in the lower ablation zone

- Snow and ice albedo, which determines the fraction of incoming solar radiation that can be used to warm or melt the surface

- Firn and supraglacial processes, which determine the fraction of meltwater that refreezes or is stored in perennial aquifers/lakes before running off the ice sheet

- Developments in earth system modeling specific for GrIS SMB

These processes cannot be easily ranked for relative importance, which depends on location, time of year, and meteorological conditions. Instead, the sections are ordered to allow a logical discussion starting with SMB observations (in situ and reconstructions), then cover processes that affect the entire ice sheet (synoptic circulation, clouds), continue with processes that regionally affect melt rate (albedo and turbulence), and end with processes that determine the fate of the meltwater before it leaves the ice sheet system. We conclude our synopsis with conclusions and a brief outlook.

\section{Definitions}

A thorough understanding of ice sheet mass changes is rooted in the quantification of individual mass balance components. This requires the closure of four balances. First, ice sheet mass balance (MB) is controlled by the difference between net mass gains at the surface, expressed by the surface mass balance (SMB), and mass lost by solid ice discharge across the ice sheet grounding line $(D)$, integrated over a year. It is often expressed in Gt year ${ }^{-1}$ (1 Gt is the mass of $1 \mathrm{~km}^{3}$ of water):

$\mathrm{MB}=\mathrm{dM} / \mathrm{dt}=\mathrm{SMB}-\mathrm{D}\left[{\left.\mathrm{Gt} \mathrm{yr}^{-1}\right]}^{-1}\right.$
Second, the SMB as used here is the sum of all sources and sinks of mass in the column extending from the ice sheet surface to the firn/ice interface:

$\mathrm{SMB}=\mathrm{P}_{\text {tot }}-\mathrm{SU}_{\text {tot }}-\mathrm{ER}_{\mathrm{ds}}-\mathrm{RU}\left[\mathrm{Gt} \mathrm{yr}^{-1}\right]$

where $P_{\text {tot }}$ is total precipitation (sum of snowfall (SN) and rainfall (RA)), $\mathrm{SU}_{\text {tot }}$ is total sublimation (from the surface and from drifting snow particles), $\mathrm{ER}_{\mathrm{ds}}$ is erosion of surface snow by divergence of the drifting snow transport, and RU is meltwater runoff. SMB in Eq. (2) is also referred to as climatic mass balance [15], to distinguish it from processes taking place purely at the surface. Because $D$ is definite positive, a situation with negative SMB recurring annually makes MB definite negative and is sometimes referred to as a tipping point for GrIS mass loss.

Third, to obtain runoff (RU), we must also quantify the liquid water balance, which we define here as the sum of all sources and sinks of liquid water in the column extending from the ice sheet surface to the firn/ice interface:

$\mathrm{RU}=\mathrm{RA}+\mathrm{CO}+\mathrm{ME}-\mathrm{RT}-\mathrm{RF}\left[\mathrm{Gt} \mathrm{yr}^{-1}\right]$

where RA is rainfall, $\mathrm{CO}$ is condensation of water vapor at the ice sheet surface, ME is surface meltwater production, RT is retention of liquid water in the snow/firn by capillary forces, and RF is refreezing of liquid water at or below the surface.

Finally, surface sublimation in (2) and condensation and melt in (3) depend on the surface energy balance (SEB), the sum of all energy fluxes towards and away from the surface:

$$
\begin{aligned}
\mathrm{M} & =\mathrm{SW}_{\text {in }}+\mathrm{SW}_{\text {out }}+\mathrm{LW}_{\text {in }}+\mathrm{LW}_{\text {out }}+\mathrm{SHF}+\mathrm{LHF}+\mathrm{G}_{\mathrm{s}} \\
& =\mathrm{SW}_{\text {in }}(1-\alpha)+\mathrm{LW}_{\text {in }}-\sigma \mathrm{T}_{\mathrm{s}}^{4}+\mathrm{SHF}+\mathrm{LHF}+\mathrm{G}_{\mathrm{s}}\left[\mathrm{W} \mathrm{m}^{-2}\right]
\end{aligned}
$$

where $M$ is melt energy, SW and LW are shortwave (solar) and longwave (terrestrial) radiation fluxes, respectively, SHF and LHF are the turbulent surface fluxes of sensible and latent heat, $G_{\mathrm{s}}$ is the subsurface (conductive) heat flux, $\alpha$ the surface broadband albedo, $\sigma$ the constant of Stefan Boltzmann $\left(\sigma=5.67 \times 10^{-8} \mathrm{~W} \mathrm{~m}^{-2} \mathrm{~K}^{-4}\right)$, and $T_{\mathrm{s}}$ snow/ice surface (skin) temperature. In Eq. 4, it is assumed that the surface emissivity for longwave radiation equals unity and that no shortwave radiation penetrates below the snow/ice surface, in which case, the SEB can be solved by iteratively searching a value of $T_{\mathrm{s}}$ for which the SEB is closed. When $T_{\mathrm{s}}>0{ }^{\circ} \mathrm{C}$, it is reset to $0{ }^{\circ} \mathrm{C}$ and the residual energy is invested in melting $(M>0)$.

The accumulation and ablation zones of an ice sheet are defined as the areas where (local) surface mass balance (expressed in mm w.e. year ${ }^{-1}$ or $\mathrm{kg} \mathrm{m}^{-2}$ year ${ }^{-1}$ ) is positive and negative, respectively (blue and red areas in Fig. 1). 
These two zones are separated by the equilibrium line, where $\mathrm{SMB}=0$.

\section{Surface Mass Balance Contribution to Ice Sheet Mass Loss}

Before exploring the contribution of surface processes to recent GrIS mass loss, it is instructive to list the typical magnitude of individual SMB components for a period during which the contemporary ice sheet was in approximate balance. Two recent compilations of GrIS MB studies suggest that this was the case during the early 1990s [42, 52]. Independent estimates of $D$ from radar interferometry and feature tracking [30] and SMB from regional climate modeling [104] seem to confirm that discharge in the mid-1990s was similar to average SMB during the preceding decades (1960s to 1980s), reminiscent of ice flow that has adjusted to SMB forcing (Fig. 2). For the climatological period 1961-1990, modeled total annual precipitation on the ice sheet $P_{\text {tot }}$ averaged $\approx 700 \mathrm{Gt}$ year $^{-1}, \mathrm{SU}_{\text {tot }} \approx 40 \mathrm{Gt}_{\text {year }}{ }^{-1}$, $\mathrm{RU} \approx 260 \mathrm{Gt}$ year $^{-1}$, and $\mathrm{ER}_{\mathrm{ds}} \approx 0$, resulting in $\mathrm{SMB} \approx 400 \pm 70 \mathrm{Gt} \mathrm{year}^{-1}$ [104]. The SMB uncertainty estimate is based on a comparison with SMB observations from the accumulation and ablation zones $[75,76]$. Combined with the estimated 1996 value for discharge $D \approx 410 \pm 20 \mathrm{Gt} \mathrm{year}^{-1}$ [30], this yields a near-zero GrIS mass balance (SMB- $D$ ), but we also note that the large uncertainty margins leave ample room for an undetected mass imbalance in this period, as was previously suggested [87].

A significant summer warming of $\approx 2{ }^{\circ} \mathrm{C}$ since the early 1990s [4, 41] increased RU by more than $40 \%$ while precipitation and sublimation did not appreciably change; meanwhile - although not directly affecting RU—winter temperatures along the west coast of Greenland increased by around $5{ }^{\circ} \mathrm{C}$ ([41], updated analysis). $D$ also increased in a spatially and temporally complex way [22], to stabilize in 2010 at an $\approx 30 \%$ elevated level (Fig. 2). This resulted in a 2011-2015 average GrIS mass loss in excess of $300 \mathrm{Gt} \mathrm{year}^{-1}$ ( $\pm 30 \%$, Fig. 2), a substantial imbalance of $45 \%$ when compared to the average annual mass gain by accumulation $\left(P_{\text {tot }}-\mathrm{SU}_{\mathrm{tot}}\right)$. Using long-term (1991-2015) trends to perform the partitioning, $61 \%$ of the recent mass loss can be ascribed to the decrease in SMB and the remainder to the increase in $D$ ([104], Fig. 2). Shorter-term periods confirm this dominance of SMB in forcing recent GrIS mass loss: Enderlin et al. [30] show that between 2000 and 2005, the increase in discharge accounted for $58 \%$ of the mass loss, decreasing to $36 \%$ between 2005 and 2009 and 32\% between 2009 and 2012. Although important locally, ice-sheet integrated sublimation and erosion are relatively constant from year to year, and therefore do not contribute significantly to mass trends [61]. In the remainder of this paper, we focus on SMB processes that have dominated GrIS mass loss in recent decades, i.e., melt and runoff.

\section{Surface Mass Balance Observations for Model Evaluation}

The scarce in situ observations provide insufficient coverage to produce detailed GrIS SMB maps in space and time. That is why (regional) climate models are often used to produce these maps. In situ observations remain essential for assessing and minimizing the uncertainties in modeled GrIS SMB products.
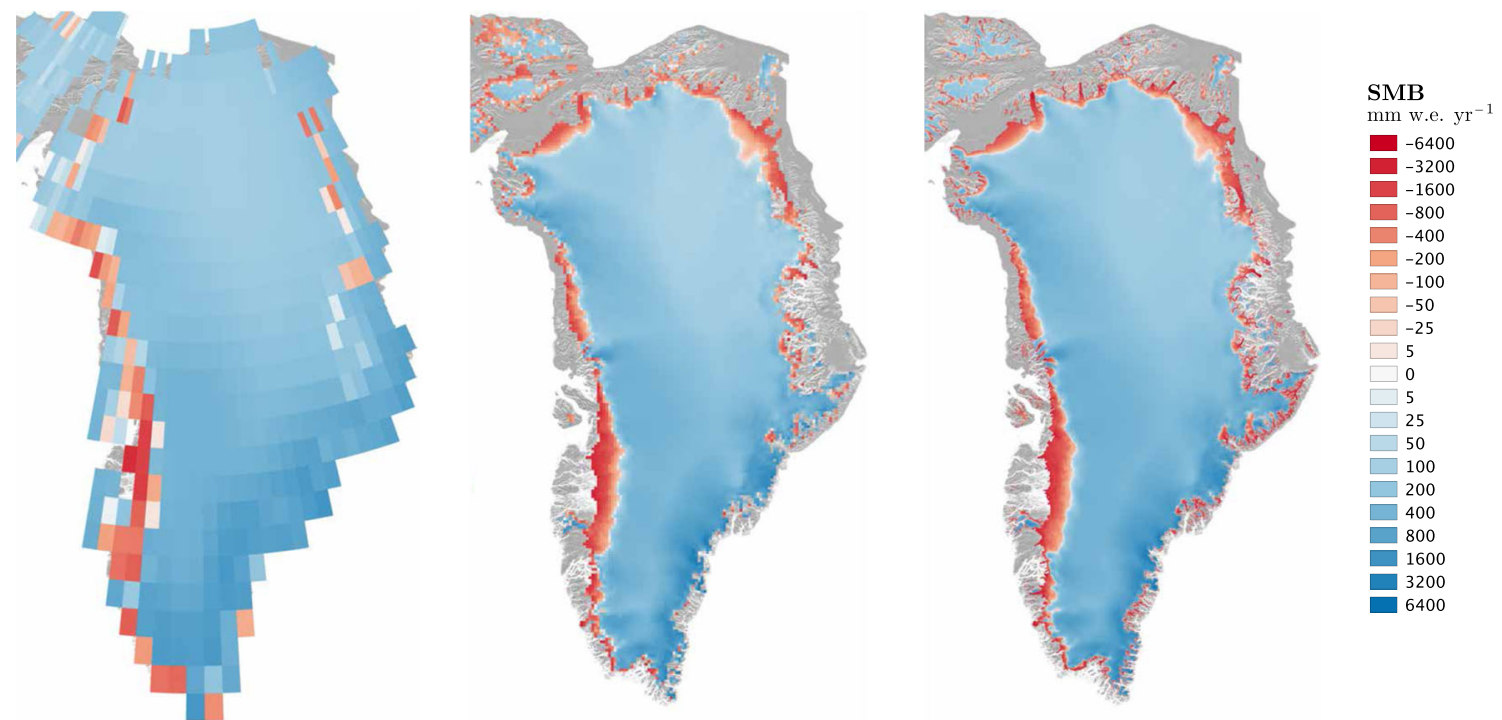

Fig. 1 Maps of modeled GrIS SMB at horizontal resolutions of $\sim 100 \mathrm{~km}$, using a global climate model (left, [106]), $10 \mathrm{~km}$ using dynamical downscaling with a regional climate model (middle, [73]), and of $1 \mathrm{~km}$, using statistical downscaling (right, [74]) 
Fig. 2 Example time series of modeled Greenland ice sheet MB component time series (1958 2015, [104]). Discharge between 1958 and 1995 is assumed equal to the 1996 value

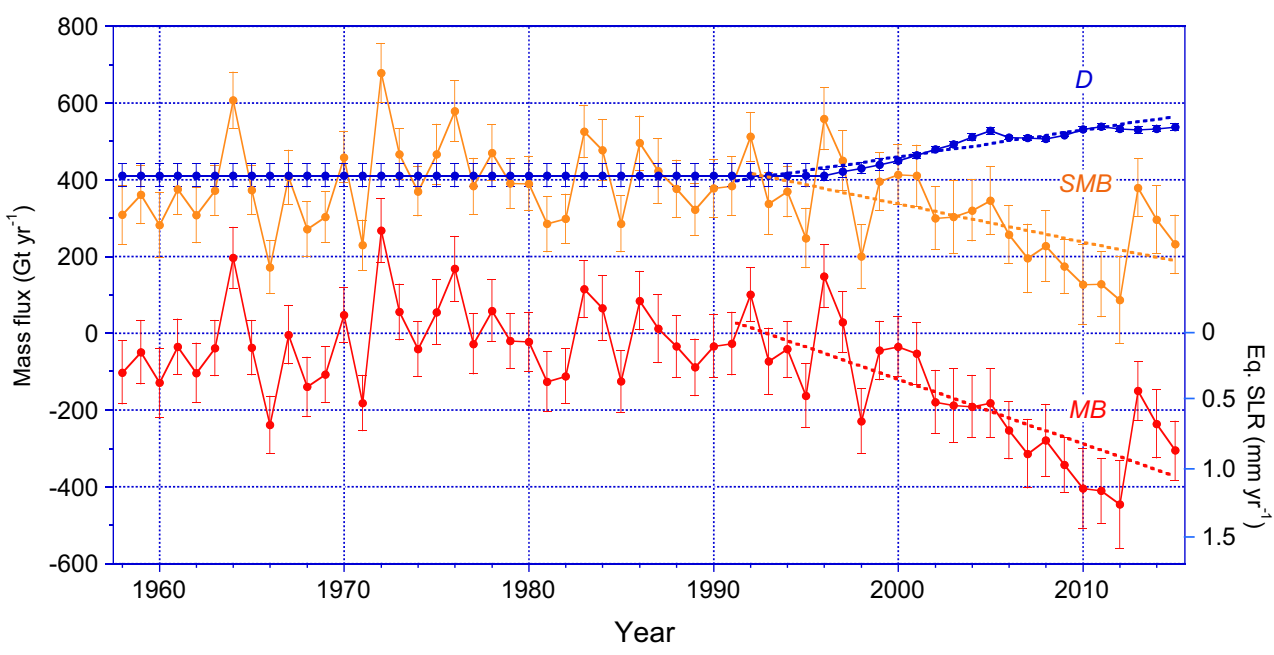

The use of inaccurate and/or different ice masks and elevation models has so far prevented a fully comprehensive intercomparison of gridded GrIS SMB products, although some useful preliminary work has been undertaken [109]. Recently, the Randolph Glacier Inventory [81] and Greenland Ice Mapping Project (GIMP, [49]) have yielded high-resolution digital elevation models (DEMs) and glacier outlines of the GrIS and its peripheral glaciers and ice caps (GICs), including floating sections, representing improved boundary conditions for numerical modeling and statistical downscaling.

Another recent milestone for model evaluation is the compilation of historical Greenland ablation measurements [65], providing important constraints on GrIS marginal ablation and runoff. A similarly important development is the observation of snow accumulation using radar operated from airplanes [55, 63, 80], strongly improving the coverage of observed SMB in the GrIS accumulation zone. This is especially important because of previously reported large discrepancies in absolute values of GrIS accumulation [2, 9, 40].

Currently available gridded SMB fields from regional climate models (RCMs, e.g., Fig. 1b) and statistically downscaled atmospheric reanalyses in general agree reasonably well with these observations $[33,36,58,64,73,75,76$, $112]$, but marginal outlet glaciers and peripheral ice caps remain poorly resolved at resolutions lower than $\sim 1 \mathrm{~km}$ [102]. For instance, when statistically downscaling RCM output from 11 to $1 \mathrm{~km}$ and using realistic ice albedo values for narrow and often relatively dark glacier tongues, Noël et al. [74] found a runoff increase of up to $30 \%$ (Fig. 1c). The significant correlation often reported for modeled SMB products on 5-20 km resolutions is therefore likely to be at least in part caused by compensating errors (e.g., a combination of underestimated snowfall and underestimated runoff), so that for now, the relatively large $( \pm 20 \%)$ uncertainty in GrIS integrated SMB values remains.

\section{Twentieth Century Greenland Ice Sheet Surface Mass Changes}

To assess its historical significance, it is useful to compare contemporary GrIS surface mass loss with historical SMB reconstructions. Here, we define "historical" as twentieth century but pre-1957/58, the International Geophysical Year (IGY) from which time onwards, reliable atmospheric reanalysis data are available for the Northern Hemisphere, e.g., the European Centre for Medium-Range Weather Forecasts (ECMWF) 40-year Reanalysis (ERA-40, [100]) and the ECMWF Interim Reanalysis (ERA-I) for 1979-present [25].

Wilton et al. [112] statistically downscaled the Twentieth Century Reanalysis (20CR), based on the National Center for Environmental Predictions (NCEP) Global Forecast System (GFS) model [17], before 1979 and ERA-I from 1979 onwards, to calculate GrIS SMB for the period 1870-2012 on a $1-\mathrm{km}$ grid, thereby improving upon the $5-\mathrm{km}$ product of Hanna et al. [40]. Apart from the increase in runoff and associated drop in SMB since $\approx 1995$, their reconstruction reports importantly higher $(\approx 15 \%)$ precipitation and lower $(\approx 20 \%)$ runoff values in the pre-IGY period, resulting in up to $\approx 40 \%$ higher SMB values compared to the $5-\mathrm{km}$ product. Box [4] uses a combination of accumulation derived from ice cores, regional climate model output and temperature observations from manned coastal stations to reconstruct GrIS SMB between 1840 and 2010. They find significant differences with the reconstruction of Hanna et al. [40] for their overlapping period (1871-2008), with lower historical values and no (negative) trend in SMB.

Fettweis et al. [33] forced the regional model MAR with two historical reanalysis data sets (ERA-20c, 20CRv2); they found GrIS SMB values that are lower than in Box [4] before 1945 but agree well after that, resulting in a generally positive SMB trend through the first half of the last century, mainly due to an accumulation increase. These results qualitatively agree 
with Kjeldsen et al. [53], who used historical aerial photography to assess twentieth century GrIS mass loss and found on average $52 \mathrm{Gt}_{\text {year }}{ }^{-1}$ lower SMB values for the period 1900 1983 than in 1983-2003, although this difference falls within the estimated uncertainties.

We conclude that the results of these studies are not sufficiently similar to draw firm conclusions about the pre-IGY evolution of GrIS SMB and therefore cannot be used to assess the historical significance of contemporary (post-1990) surface mass losses.

\section{Large-Scale Atmospheric Circulation}

Changes in Greenland summer near surface air temperature are caused by changes in the local heat balance of the atmosphere, including vertical mixing in the boundary layer and radiative heat exchange by greenhouse gases, and also by variability in the direction and strength of the regional/largescale atmospheric circulation in combination with regional temperature gradients. Fettweis et al. [32] used a circulation type classification to show that since 2003, phases with a negative North Atlantic Oscillation (NAO) index occurred more frequently in summer, leading to increased northward transport of warm air to west Greenland, explaining an estimated $70 \%$ of the recent summer warming. Mioduszewski et al. [70] developed a summer Arctic synoptic climatology by applying self-organizing maps to daily $500-\mathrm{hPa}$ geopotential height fields of the Modern Era Retrospective Analysis for Research and Applications reanalysis (MERRA, 1979-2014). The study confirms that the largest positive GrIS melt anomalies occur in concert with strong northward transport of heat and moisture. A third study confirms this by showing that recent increases in GrIS summer melt occurred synchronously with a significant upward trend in the Greenland Blocking Index in summer, representing increased high-pressure blocking over Greenland and warm air advection (Fig. 3, [44]). In July 2012, this circulation anomaly and associated melt-albedo feedback (see "Albedo" section) culminated in an exceptional melt event, in which almost the entire ice sheet surface experienced at least some melt [43, 72]; the associated runoff peak in west Greenland destroyed infrastructure that had been in place since the 1950s.

Ding et al. [26] indicate that the circulation anomaly described above originates in the tropical Pacific and that it likely reflects natural decadal variability, which may also have a negative impact on sea ice cover in the Arctic Ocean [27]. This hypothesis may be supported by the absence of persistent negative summertime NAO anomalies in future projections by CMIP5 models [32, 37], although there are deficiencies in North Atlantic jet stream representation in the climate models that make future NAO projections inconsistent and unreliable [38, 39]. Recent atmospheric circulation anomalies over Greenland in summer could also have been triggered by the Arctic Amplification of global warming, which may have produced a more meandering jet stream flow and increased blocking over Greenland during the last decade [44, 77-79, 98]. This pronounced variability and possible sustained forcing of the large-scale circulation and therefore SMB imposes severe limits on the unambiguous detection of long-term GrIS mass loss acceleration [113] that can reliably be attributed to anthropogenic climate change. This is despite Greenland being one of the hotspots of recent global warming since the early 1990 s.

\section{Clouds, Radiation, and Turbulence}

Melt rate at the surface of the GrIS is determined by the surface energy balance (SEB, Eq. 4). This implies that models that assess present-day and predict future GrIS surface melt rates must preferably explicitly calculate the individual SEB components. In turn, these models must be evaluated with as many as possible in situ SEB observations, to assess whether the partitioning of melt energy, and therefore the sensitivity of melt to changing atmospheric/surface conditions is correctly represented [62, 73, 75, 76]. An accurate observational estimate of melt energy requires dedicated experiments or automatic weather stations (AWS) that are operated at the ice sheet surface and measure all relevant parameters (including all radiation fluxes) sufficiently accurately to close the SEB and calculate melt energy as a residual; such stations are, e.g., operated at Summit and Swiss Camp by GC-Net [20], in the PROMICE network [14], and along the K-transect in west Greenland [57, 90].

Apart from evaluation purposes, in situ SEB data themselves also lead to discovery. For instance, AWS data revealed that occasional melt on the highest parts of the GrIS is especially sensitive to the optical thickness, emissivity, and phase (ice, water, or mixed) of clouds [3, 107] mainly enhancing incoming longwave radiation. In contrast, melt variability in the low-albedo ablation zones is mainly driven by incoming solar radiation (Box and others, 2012), highlighting the complex role of cloud changes on GrIS SMB. Recent results indicate that a decrease in summer cloud cover driven by the above-mentioned increased blocking has largely driven increased SMB losses over the last two decades [47].

Another recent finding is the dominant contribution of turbulent sensible heat fluxes to melt energy during strong melt events along the GrIS margins. Neither climate models [73] nor calculations from weather stations [31] reproduce these melt peaks well, which may be associated with the breakdown of turbulence parameterizations under these conditions or the fact that narrow boundary-layer jets (so-called barrier winds), driven by the temperature contrast between tundra and ice sheet, are poorly resolved. This is highly relevant, as it is 
Fig. 3 Average (red contours) and summer 2012 (June, July, August) $700 \mathrm{hPa}$ height (blue contours), wind anomaly (blue arrows), and temperature anomaly $\left({ }^{\circ} \mathrm{C}\right)$ from ERA-Interim



expected that these conditions will occur more frequently when the GrIS retreats onto land and more tundra is exposed. What may improve the simulation of turbulent energy fluxes is a more realistic $2 \mathrm{D}$ field of surface aerodynamic roughness [91], rather than prescribing a single constant value for snow and ice.

\section{Albedo}

When integrated over the year, absorbed shortwave radiation is the dominant source for melt energy at the GrIS surface [6, 57] and can even be used as predictor for GrIS mass balance [16]. The absorbed (or "net") shortwave radiation is determined to first order by the shortwave reflectivity or albedo of the ice/snow surface, a very sensitive variable when modeling GrIS SMB [75, 76, 101]. In the absence of impurities, albedo ranges from over 0.85 for freshly deposited dry, finegrained snow, to 0.7 for wet snow, and to below 0.55 for bare glacier ice. This means that the presence/absence of snow at the surface represents a factor of three differences in absorbed solar energy.

GrIS surface albedo variability can be determined from optical satellite remote sensing and ground observations. The ground data come from 3 to $5-\mathrm{m}$ high masts that often contain errors from sensor tilt for which corrections [111] and quality assurance schemes ([5]) exist. In areas with heterogeneous surfaces, e.g., fractional snow cover, the in situ observation of albedo with a small footprint is not always representative of the much greater area observed by the satellite; unmanned airborne vehicles (UAV's) may be deployed to understand this spatial scale gap [88].

Over bare ice, the accumulation of impurities (soot, dust, microbiological material) can decrease albedo to values below 0.3, further enhancing ablation rates during summer (Fig. 4). Estimates of the radiative impact due to algae growing at the ice sheet surface indicate that bare ice albedo is reduced more by algal growth than non-algal impurities including dust [71, 94], warranting the inclusion of this process in ice albedo models $[18,19]$.

Over snow, a powerful positive feedback exists between melt and albedo: snow grains grow rapidly when they get wet, enhancing forward scattering and absorption in the snowpack, significantly reducing the albedo, especially in the nearinfrared part of the spectrum. When broadband snow albedo during melt decreases from 0.85 to 0.70 (e.g., [12]), this doubles the absorption of shortwave radiation, which in turn increases snow grain metamorphism, further darkening the snow, further enhancing melt. Because $>90 \%$ of the GrIS is snow covered, this process is highly relevant in a warming climate. The ultimate impact of the albedo melt feedback is modulated by clouds and further depends on the duration of the amplification process. Upon accumulation of fresh snow, albedo is reset to the fresh snow value.

Following the recent lengthening of the melt season over the snow-covered part of the GrIS, one would expect a decadal albedo decline. Indeed, from moderate-resolution imaging spectroradiometer (MODIS) satellite retrievals, available 
Fig. 4 Left: map of summer (June, July, August) MODIS Collection 6 albedo change between 2000 and 2017 (from regression, unitless) for

Greenland glaciated areas with results shown only where the change exceeds one standard error of the regression fit (data processed after [6-7]). Right: photo of impurity rich bare ice surface at the south Greenland QAS_L PROMICE.dk climate station where surface albedo reaches a minimum of 0.20 in summer (photo J. Box)


since 2000/2002 from the NASA Terra/Aqua satellites, respectively, multiple recent studies reported a decadal darkening of the GrIS surface [1, 6, 29, 95, 99]. At higher latitudes, part of this trend has been attributed to MODIS sensor degradation $[10,84]$, which is corrected for in the latest MODIS Collection 6 product; the latter suggests a $-1.2+/-0.9 \%$ summer seasonal albedo reduction between 2000 to 2017 (Fig. 4; [7, 99]). While at the full scale of the ice sheet, the albedo trend from 2000 to 2017 is hardly statistically significant, across much of the ice sheet ablation area, the local 18-year trend exceeds both the stated accuracy of the MODIS Collection 6 product and the standard error of the trend fits (Fig. 4). The ablation area albedo reduction results from some combination of reduced snow covered area and duration and biological darkening. The trend remains despite low melt or high snow cover years like in 2013 and 2017, respectively.

\section{Firn Processes}

Firn, the up to $\sim 100$-m thick layer of compressed snow that covers $>90 \%$ of the GrIS, plays a pivotal role in the response of the GrIS SMB to atmospheric warming. It acts as an efficient buffer for meltwater that is produced at the surface [45]; models estimate that Greenland's lower peripheral ice caps have lost most of their refreezing capacity $[75,76]$, but that for the highly elevated GrIS, about $45 \%$ of the meltwater is still retained in the firn layer, either by capillary forces or by refreezing [92]. This vertical meltwater penetration occurs in a heterogeneous fashion, bypassing dry and cold layers through "pipes" [50]. Upon refreezing, the release of latent heat can warm the firn layer in the lower accumulation zone by more than $10{ }^{\circ} \mathrm{C}$ when compared to the annual mean surface temperature [67]; the gradual increase in GrIS melt can be tracked from the observation of decadal firn warming [21, 83]. Ice lenses that form as a result of refreezing decrease permeability and firn storage of meltwater, limiting the availability of the deeper pore space for meltwater storage and enhancing lateral runoff [66]. The combination of high accumulation rates and strong summer melting found in the southeast and northwest of the GrIS leads to the formation of perennial firn aquifers occupying $\sim 4 \%$ of the conterminous ice sheet area with an estimated mass of $140 \pm 20 \mathrm{Gt}[35,54,56,68]$. The firn aquifer was found to exit the south eastern ice sheet via crevasses [82].

\section{Supraglacial Meltwater Retention and Runoff}

The hypsometry of the ice sheet with its steep margins and flat interior results in a rapid increase in melt area when melt reaches higher elevations (Mikkelsen and others, 2016). Van As et al. [103] show that the ice sheet's concave hypsometry adds $\sim 60 \%$ runoff to a hypothetical linearly sloping surface. In response to excessive meltwater production in recent warm summers, the distribution of supraglacial lakes on the Greenland ice sheet has migrated upglacier [34, 48] and is even predicted to extend further to elevations of $2000 \mathrm{~m}$ asl in 2100 [60]. During the record melt years of 2010 and 2012, lakes formed and drained earlier, attaining their maximum volume 38 and 20 days earlier than the 11-year average, respectively, as well as occupying a greater area and forming at higher elevations ( $>1800 \mathrm{~m}$ asl) than previously. Clustering of drainage events in space and time suggests a trigger 
mechanism that is dynamically driven by basal slip [93]. The majority of fast lake drainages occur in the southwestern sector of the ice sheet, and fewer are observed in regions with significant dynamic mass loss [89]. The lakes absorb more solar radiation than the ice surface causing a $10-35 \%$ increase in ice surface ablation rates relative to surrounding bare ice areas [96], which is likely to enhance the development of lake basins on the ice surface. Rapid lake drainage occurs in a few hours [28], producing kilometer-long fractures that may trigger further localized lake drainage [34]. The time between meltwater generation and its discharge at the ice sheet margin can be in excess of 1 week, depending on proximity to the ice sheet margin, abundance of supraglacial lakes, and hydraulic efficiency of the subglacial drainage system [11, 85, 103].

\section{Global Reanalyses and Earth System Models}

Global reanalysis datasets and earth system models (ESMs) provide 4D representations of the global coupled climate system and are therefore especially suitable for diagnosing and predicting the past, present, and future state of GrIS surface processes. However, the standard horizontal resolution of these (typically $30-100 \mathrm{~km}$ ) is currently too coarse to properly resolve the GrIS ablation zone and its steep coastal topography, which induces orographic precipitation (Fig. 1a). Nonetheless, with increasing availability of remotely-sensed and in-situ observations to improve sub-grid parameterizations, and more computing power to increase resolution, the outlook for GrIS SMB modeling as part of global models is promising. A new generation of variable-resolution ESMs [86] could further accelerate their application.

For these reasons, priority should be given to further improve the parameterization of ice sheet surface processes in ESMs and assimilation systems, current examples include EC-Earth [46] and CESM [59, 106, 110], and to carry out inter-comparison projects for ESM land surface modules [105]. These efforts directly benefit the representation of ice sheet processes in global/regional reanalysis products, e.g., the Arctic System reanalysis [8] and the Modern-Era Retrospective analysis for Research and Applications, version 2 (MERRA-2, [24]), based on the Goddard Earth Observing System Data Assimilation System Version 5 (GEOS-5, [23]).

\section{Conclusions and Outlook}

The Greenland ice sheet (GrIS) has experienced significant mass losses since the early 1990s and currently represents the largest single contributor to ongoing mean sea level rise. The mass loss is dominated by a decrease in the surface mass balance (SMB), i.e., the sum of mass fluxes towards (mainly snowfall) and away from (mainly meltwater runoff) the surface. In this paper, we review results of recent (post IPCC AR5) research results in the field of GrIS SMB processes.

Since IPCC AR5, the powerful combination of remote sensing, in situ observations, and dynamical/statistical regional climate modeling has yielded many new discoveries and insights into the workings of GrIS surface processes and how these have contributed to recent GrIS mass changes. It is clear that robust predictions of future GrIS surface mass loss can only be made using models that explicitly simulate largescale circulation changes in the Arctic and that include parameterizations of newly discovered processes. Many of these are currently not or not well represented, such as bio-albedo, ice lenses and lateral meltwater transport, heterogeneous vertical meltwater transport, mixed-phase clouds, and turbulent heat exchange over rough ice surfaces.

Upon inclusion of these processes in model simulations of Greenland climate and SMB and with further development of modeling techniques, we deem it possible to halve the current uncertainty in accumulation/ablation of $\sim 10 / 20$ to $\sim 5 / 10 \%$ in the coming decade. This will significantly reduce the uncertainty in SMB and improve the accuracy of predictions of future GrIS mass loss.

\section{Compliance with Ethical Standards}

Conflict of Interest On behalf of all authors, the corresponding author states that there is no conflict of interest.

Human and Animal Rights and Informed Consent This article does not contain any studies with human or animal subjects performed by any of the authors.

Open Access This article is distributed under the terms of the Creative Commons Attribution 4.0 International License (http:// creativecommons.org/licenses/by/4.0/), which permits unrestricted use, distribution, and reproduction in any medium, provided you give appropriate credit to the original author(s) and the source, provide a link to the Creative Commons license, and indicate if changes were made.

\section{References}

1. Alexander PM, Tedesco M, Fettweis X, van de Wal RSW, Smeets CJPP, van den Broeke MR. Assessing spatiotemporal variability and trends in modelled and measured Greenland ice sheet albedo (2000-2013). Cryosphere. 2014;8:2293-312. https://doi.org/10. 5194/tc-8-2293-2014.

2. Bales RC, Guo Q, Shen D, McConnell JR, Du G, Burkhart JF, et al. Annual accumulation for Greenland updated using ice core data developed during 2000-2006 and analysis of daily coastal meteorological data. J Geophys Res. 2009;114:D06116. https:// doi.org/10.1029/2008JD011208.

3. Bennartz R, Shupe M, Turner D, Walden V, Steffen K, Cox C, et al. July 2012 Greenland melt extent enhanced by low-level liquid clouds. Nature. 2013;496:83-6.

4. Box JE. Greenland ice sheet mass balance reconstruction. Part II: surface mass balance (1840-2010). J Clim. 2013;26:6974-89. https://doi.org/10.1175/JCLI-D-12-00518.1. 
5. Van As D. Warming, glacier melt and surface energy budget from weather station observations in the Melville Bay region of northwest Greenland. J. Glaciol. 2011;57:208-20.

6. Box JE, Fettweis X, Stroeve JC, Tedesco M, Hall DK, Steffen K. Greenland ice sheet albedo feedback: thermodynamics and atmospheric drivers. Cryosphere. 2012;6:821-39. https://doi.org/10. 5194/tc-6-821-2012.

7. Box JE, van As D, Steffen K, the PROMICE project team. Greenland, Canadian and Icelandic land-ice albedo grids (2000 2016). Geol Surv Den Greenl Bull. 2017b;38:53-6.

8. Bromwich DH, Wilson AB, Bai L-S, Moore GW, Bauer P. A comparison of the regional Arctic System Reanalysis and the global ERA-Interim reanalysis for the Arctic. Q J R Meteorl Soc. 2015; https://doi.org/10.1002/qj.2527.

9. Burgess EW, Forster RR, Box JE, Mosley-Thompson E, Bromwich DH, Bales RC, et al. A spatially calibrated model of annual accumulation rate on the Greenland ice sheet (1958-2007). J Geophys Res. 2010;115:F02004. https://doi.org/10.1029/ 2009JF001293.

10. Casey KA, Polashenski CM, Chen J, Tedesco M. Impact of MODIS sensor calibration updates on Greenland ice sheet surface reflectance and albedo trends. Cryosphere 2017;11:1781-1795, https://doi.org/10.5194/tc-2017-38.

11. Chandler DM, Wadham JL, Lis GP, Cowton T, Sole A, Bartholomew I, et al. Evolution of the subglacial drainage system beneath the Greenland ice sheet revealed by tracers. Nat Geosci. 2013;6:195-8. https://doi.org/10.1038/ngeo 1737.

12. Charalampidis C, van As D, Box JE, van den Broeke MR, Colgan WT, Doyle SH, et al. Changing surface-atmosphere energy exchange and refreezing capacity of the lower accumulation area, West Greenland. Cryosphere. 2015;9:2163-81. https://doi.org/10. 5194/tc-9-2163-2015.

13. Church JA, Clark PU, Cazenave A, Gregory JM, Jevrejeva S, Levermann A, et al. Sea level change. In: Stocker TF, Qin D, Plattner G-K, Tignor M, Allen SK, Boschung J, Nauels A, Xia Y, Bex V, Midgley PM, editors. Climate change 2013: the physical science basis. Contribution of working group I to the Fifth Assessment Report of the Intergovernmental Panel on Climate Change. Cambridge: Cambridge University Press; 2013.

14. Citterio M, van As D, Ahlstrøm AP, Andersen ML, Andersen SB, Box JE, et al. Automatic weather stations for basic and applied glaciological research. Geol Surv Den Greenl Bull. 2015;33:6972.

15. Cogley JG, Hock R, Rasmussen LA, Arendt AA, Bauder A, Braithwaite RJ, et al. Glossary of glacier mass balance and related terms, IHP-VII Technical Documents in Hydrology No. 86, IACS Contribution No. 2. Paris: UNESCO-IHP; 2011.

16. Colgan W, Box JE, Fausto RS, van As D, Barletta V, Forsberg R. Surface albedo as a proxy for the mass balance of Greenland's terrestrial ice. Geol Surv Den Greenl Bull. 2014;31:91-4.

17. Compo GP, Whitaker JS, Sardeshmukh PD, Matsui N, Allan RJ, Yin X, et al. The twentieth century reanalysis project. Q J R Meteorl Soc. 2011;137:1-28. https://doi.org/10.1002/qj.776.

18. Cook JM, Hodson AJ, Taggart AJ, Mernild SH, Tranter M. A predictive model for the spectral "bioalbedo" of snow. J Geophys Res Earth Surf. 2017a;122:434-54. https://doi.org/10. 1002/2016JF003932.

19. Cook JM, Hodson AJ, Gardner AS, Flanner M, Tedstone AJ, Williamson C, et al. Quantifying bioalbedo: a new physicallybased model and critique of empirical methods for characterizing biological influence on ice and snow albedo. Cryosphere Discuss. 2017b; https://doi.org/10.5194/tc-2017-73.

20. Cox CJ, Walden VP, Compo GP, Rowe PM, Shupe MD, Steffen K. Downwelling longwave flux over summit, Greenland, 2010 2012: analysis of surface-based observations and evaluation of
ERA-interim using wavelets. J Geophys Res. 2014;119:12,31737. https://doi.org/10.1002/2014JD021975.

21. Cox C, Humphrey N, Harper J. Quantifying meltwater refreezing along a transect of sites on the Greenland ice sheet. Cryosphere. 2015;9:691-701. https://doi.org/10.5194/tc-9-691-2015.

22. Csatho BM, Schenk AF, van der Veen CJ, Babonis G, Duncan K, Rezvanbehbahani S, et al. Laser altimetry reveals complex pattern of Greenland ice sheet dynamics. Proc Natl Acad Sci. 2014; https://doi.org/10.1073/pnas.1411680112.

23. Cullather R, Nowicki S, Zhao B, Suarez MJ. Evaluation of the surface representation of the Greenland ice sheet in a general circulation model. J Clim. 2014;27:4835-56. https://doi.org/10. 1175/JCLI-D-13-00635.1.

24. Cullather RI, Nowicki SM, Zhao B, Koenig LS. A characterization of Greenland ice sheet surface melt and runoff in contemporary reanalyses and a regional climate model. Front Earth Sci. 2016; 4 https://doi.org/10.3389/feart.2016.00010.

25. Dee DP, Uppala SM, Simmons AJ, Berrisford P, Poli P, Kobayashi $\mathrm{S}$, et al. The ERA-Interim reanalysis: configuration and performance of the data assimilation system. Q J R Meteorol Soc. 2011;137:553-97. https://doi.org/10.1002/qj.828.

26. Ding Q, Wallace JM, Battisti DS, Steig EJ, Gallant AJE, Kim H-J, et al. Tropical forcing of the recent rapid Arctic warming in northeastern Canada and Greenland. Nature. 2014;509:209-12.

27. Ding Q, Schweiger A, l'Heureux M, Battisti DS, Po-Chedley S, Johnson NC, et al. Influence of high-latitude atmospheric circulation changes on summertime Arctic sea ice. Nat Clim Chang. 2017:1758-6798. https://doi.org/10.1038/nclimate3241.

28. Doyle SH, Hubbard AL, Dow CF, Jones GA, Fitzpatrick A, Gusmeroli A, et al. Ice tectonic deformation during the rapid in situ drainage of a supraglacial lake on the Greenland ice sheet. Cryosphere. 2013;7:129-40.

29. Dumont M, Brun E, Picard G, Michou M, Libois Q, Petit J-R, et al. Contribution of light-absorbing impurities in snow to Greenland's darkening since 2009. Nat Geosci. 2014;7:509-12.

30. Enderlin EM, Howat IM, Jeong S, Noh M-J, van Angelen JH, van den Broeke MR. An improved mass budget for the Greenland ice sheet. Geophys Res Lett. 2014;41:866-72. https://doi.org/10. 1002/2013GL059010.

31. Fausto RS, van As D, Box JE, Colgan W, Langen PL, Mottram $\mathrm{RH}$. The implication of nonradiative energy fluxes dominating Greenland ice sheet exceptional ablation area surface melt in 2012. Geophys Res Lett. 2016;43 https://doi.org/10.1002/ 2016GL067720.

32. Fettweis X, Hanna E, Lang C, Belleflamme A, Erpicum M, Gallée $\mathrm{H}$. Brief communication "Important role of the mid-tropospheric atmospheric circulation in the recent surface melt increase over the Greenland ice sheet". Cryosphere. 2013;7:241-8. https://doi.org/ 10.5194/tc-7-241-2013.

33. Fettweis X, Box JE, Agosta C, Amory C, Kittel C, Lang C, et al. Reconstructions of the 1900-2015 Greenland ice sheet surface mass balance using the regional climate MAR model. Cryosphere. 2017;11:1015-33. https://doi.org/10.5194/tc-111015-2017.

34. Fitzpatrick AAW, Hubbard AL, Box JE, Quincey DJ, van As D, Mikkelsen APB, et al. A decade (2002-2012) of supraglacial lake volume estimates across Russell Glacier, West Greenland. Cryosphere. 2014;8:107-21.

35. Forster RR, Box JE, van den Broeke MR, Miège C, Burgess EW, van Angelen JH, et al. Extensive liquid meltwater storage in firn within the Greenland ice sheet. Nat $\mid$ Geosci. 2014;7:95-8. https:// doi.org/10.1038/ngeo2043.

36. Franco B, Fettweis X, Lang C, Erpicum M. Impact of spatial resolution on the modelling of the Greenland ice sheet surface mass balance between 1990-2010, using the regional climate 
model MAR. Cryosphere. 2012;6:695-711. https://doi.org/10. 5194/tc-6-695-2012.

37. Gillett NP, Fyfe JC. Annular mode changes in the CMIP5 simulations. Geophys Res Lett. 2013;40:1189-93. https://doi.org/10. 1002/grl.50249.

38. Hall R, Erdélyi R, Hanna E, Jones JM, Scaife AA. Drivers of North Atlantic polar front jet stream variability. Int J Climatol. 2015;35:1697-720. https://doi.org/10.1002/joc.4121.

39. Hanna E, Cropper TE. North Atlantic oscillation. Oxford Research Encyclopedia of Climate Science. 2017. https://doi. org/10.1093/acrefore/9780190228620.013.22.

40. Hanna E, Huybrechts P, Cappelen J, Steffen K, Bales RC, Burgess E, et al. Greenland ice sheet surface mass balance 1870 to 2010 based on twentieth century reanalysis, and links with global climate forcing. J Geophys Res. 2011;116:D24121. https://doi.org/ 10.1029/2011JD016387.

41. Hanna E, Mernild SH, Cappelen J, Steffen K. Recent warming in Greenland in a long-term instrumental (1881-2012) climatic context. I: evaluation of surface air temperature records. Environ Res Lett. 2012;7:045404. https://doi.org/10.1088/1748-9326/7/4/ 045404 .

42. Hanna E, Navarro FJ, Pattyn F, Domingues CM, Fettweis X, Ivins $\mathrm{ER}$, et al. Ice-sheet mass balance and climate change. Nature. 2013;498:51-9.

43. Hanna E, Fettweis X, Mernild SH, Cappelen J, Ribergaar MH, Shuman CA, et al. Atmospheric and oceanic climate forcing of the exceptional Greenland ice sheet surface melt in summer 2012. Int J Climatol. 2014;34:1022-37.

44. Hanna E, Cropper TE, Hall R, Richard J, Cappelen J. Greenland Blocking Index 1851-2015: a regional climate change signal. Int J Climatol. 2016;36:4847-61.

45. Harper J, Humphrey N, Pfeffer WT, Brown J, Fettweis X. Greenland ice-sheet contribution to sea-level rise buffered by meltwater storage in firn. Nature. 2013;491:240-3.

46. Helsen MM, van de Wal RSW, Reerink TJ, Bintanja R, Madsen MS, Yang S, et al. On the importance of the albedo parameterization for the mass balance of the Greenland ice sheet in EC-Earth. Cryosphere. 2017;11:1949-65.

47. Hofer S, Tedstone AJ, Fettweis X, Bamber JL. Decreasing cloud cover drives the recent mass loss on the Greenland ice sheet. Sci Adv. 2017;3:e1700584.

48. Howat IM, de la Peña S, van Angelen JH, Lenaerts JTM, van den Broeke MR. Brief Communication "Expansion of meltwater lakes on the Greenland Ice Sheet". Cryosphere. 2013;7:201-4. https:// doi.org/10.5194/tc-7-201-2013.

49. Howat IM, Negrete A, Smith BE. The Greenland Ice Mapping Project (GIMP) land classification and surface elevation data sets. Cryosphere. 2014;8:1509-18. https://doi.org/10.5194/tc-8-15092014.

50. Humphrey NF, Harper JT, Pfeffer WT. Thermal tracking of meltwater retention in Greenland's accumulation area. J Geophys Res. 2012;117 https://doi.org/10.1029/2011JF002083.

51. IPCC. In: Stocker TF, Qin D, Plattner G-K, Tignor M, Allen SK, Boschung J, Nauels A, Xia Y, Bex V, Midgley PM, editors. Climate Change 2013: the physical science basis. Contribution of working group I to the Fifth Assessment Report of the Intergovernmental Panel on Climate Change. Cambridge: Cambridge University Press; 2013. 1535 pp.

52. Khan SA, Aschwanden A, Bjørk AA, Wahr J, Kjeldsen KK, Kjaer KH. Greenland ice sheet mass balance: a review. Rep Prog Phys. 2015;78:046801. 26 pp

53. Kjeldsen KK, Korsgaard NJ, Bjørk AA, Khan SA, Box JE, Funder $\mathrm{S}$, et al. Spatial and temporal distribution of mass loss from the Greenland ice sheet since AD 1900. Nature. 2015;528:396-400. https://doi.org/10.1038/nature16183.
54. Koenig LS, Miege C, Forster RR, Bruccker L. Initial in situ measurements of perennial meltwater storage in the Greenland firn aquifer. Geophys Res Lett. 2014;41:81-5.

55. Koenig LS, Ivanoff A, Alexander PM, MacGregor JA, Fettweis X, Panzer B, et al. Annual Greenland accumulation rates (20092012) from airborne snow radar. Cryosphere. 2016;10:1739-52. https://doi.org/10.5194/tc-10-1739-2016.

56. Kuipers Munneke P, Ligtenberg SRM, van den Broeke MR, van Angelen JH, Forster RR. Explaining the presence of perennial liquid water bodies in the firn of the Greenland ice sheet. Geophys Res Lett. 2014;41 https://doi.org/10.1002/ 2013 GL058389.

57. Kuipers Munneke P, Smeets CJPP, Reijmer CH, Oerlemans J, van de Wal RSW, van den Broeke MR. The K-transect in WestGreenland: long-term 1 (2003-2016) surface energy balance observations, Arctic, Antarctic and Alpine Research. 2017.

58. Langen PL, Mottram RH, Christensen JH, Boberg F, Rodehacke $\mathrm{CB}$, Stendel M, et al. Quantifying energy and mass fluxes controlling Godthåabsfjord freshwater input in a 5-km simulation (19912012), J. Climate. 2015;28:3694-713.

59. Lawrence DM, Oleson KW, Flanner MG, Fletcher CG, Lawrence PJ, Levis S, et al. The CCSM4 land simulation, 1850-2005: assessment of surface climate and new capabilities. J. Clim. 2012;25:2240-60.

60. Leeson AA, Shepherd A, Briggs K, Howat I, Fettweis X, Morlighem $\mathrm{M}$, et al. Supraglacial lakes on the Greenland ice sheet advance inland under warming climate. Nat Clim Chang. 2015;5:51-5.

61. Lenaerts JTM, van den Broeke MR, van Angelen JH, van Meijgaard E, Déry. Drifting snow climate of the Greenland ice sheet: a study with a regional climate model. Cryosphere. 2012;6: 891-9. https://doi.org/10.5194/tc-6-891-2012.

62. Lenaerts JTM, Van Tricht K, Lhermitte S, L'Ecuyer T. Polar clouds and radiation in satellite observations, reanalyses, and climate models. Geophys Res Lett. 2017;44 https://doi.org/10.1002/ 2016GL072242.

63. Lewis G, Osterberg E, Hawley R, Whitmore B, Marshall HP, Box J. Regional Greenland accumulation variability from Operation IceBridge airborne accumulation radar. Cryosphere. 2017;11: 773-88. https://doi.org/10.5194/tc-11-773-2017.

64. Lucas-Picher P, Wulff-Nielsen M, Christensen JH, Adalgeirsdóttir G, Mottram R, Simonsen S. Very high resolution in regional climate model simulations for Greenland: identifying added value. J Geophys Res. 2012;117:D02108. https://doi.org/10.1029/ 2011JD016267.

65. Machguth H, Thomsen HH, Weidick A, Ahlstrøm AP, AbermannN J, Andersen ML, et al. Greenland surface massbalance observations from the ice-sheet ablation area and local glaciers. J Glaciol. 2016a; https://doi.org/10.1017/jog.2016.75.

66. Machguth H, MacFerrin M, van As D, Box JE, Charalampidis C, Colgan W, et al. Greenland meltwater storage in firn limited by near-surface ice formation. Nat Clim Chang. 2016b; https://doi. org/10.1038/nclimate2899.

67. Meierbachtol TW, Harper JT, Johnson JV, Humphrey NF, Brinkerhoff DJ. Thermal boundary conditions on western Greenland: observational constraints and impacts on the modeled thermomechanical state. J Geophys Res Earth Surf. 2015;120: 623-36. https://doi.org/10.1002/2014JF 003375.

68. Miège C, Forster R, Brucker L, Koenig L, Solomon DK, Paden J, et al. Spatial extent and temporal variability of Greenland firn aquifers detected by ground and airborne radars. J Geophys Res. 2016;121 https://doi.org/10.1002/2016JF003869.

69. Mikkelsen AB, Hubbard A, MacFerrin M, Box JE, Doyle SH, Fitzpatrick A, et al. Extraordinary runoff from the Greenland ice sheet in 2012 amplified by hypsometry and depleted firn retention. Cryosphere. 2016;10:1147-59. https://doi.org/10.5194/tc-101147-2016. 
70. Mioduszewski JR, Rennermalm AK, Hammann A, Tedesco M, Noble EU, Stroeve JC, et al. Atmospheric drivers of Greenland surface melt revealed by self-organizing maps. J Geophys Res. 2016;121:5095-114. https://doi.org/10.1002/2015JD024550.

71. Musilova M, Tranter M, Bamber JL, Takeuchi N, Anesio AM. Experimental evidence that microbial activity lowers the albedo of glaciers. Geochem Perspect Lett. 2016; https://doi.org/10.7185/ geochemlet.1611.

72. Nghiem SV, Hall DK, Mote TL, Tedesco M, Albert MR, Keegan $\mathrm{K}$, et al. The extreme melt across the Greenland ice sheet in 2012. Geophys Res Lett. 2012;39:L20502. https://doi.org/10.1029/ 2012GL053611.

73. Noël B, van de Berg WK, van Meijgaard E, Kuipers Munneke P, van de Wal RSW, van den Broeke MR. Evaluation of the updated regional climate model RACMO2.3: summer snowfall impact on the Greenland ice sheet. Cryosphere. 2015;9:1831-44. https://doi. org/10.5194/tc-9-1831-2015.

74. Noël B, van de Berg WJ, Machguth H, Lhermitte S, Howat I, Fettweis X, et al. A daily, $1 \mathrm{~km}$ resolution data set of downscaled Greenland ice sheet surface mass balance (1958-2015). Cryosphere. 2016;10:2361-77. https://doi.org/10.5194/tc-10-2361-2016.

75. Noël BPY, van de Berg WJ, Lhermitte S, Wouters B, Machguth H, Howat I, et al. A tipping point in refreezing accelerates mass loss of Greenland's glaciers and ice caps. Nat Commun. 2017a;8 https://doi.org/10.1038/ncomms14730.

76. Noël B, van de Berg WJ, van Wessem JM, van Meijgaard E, van As D, Lenaerts JTM, et al. Modelling the climate and surface mass balance of polar ice sheets using RACMO2, part 1: Greenland (1958-2016). Cryosphere Discuss. 2017b; https://doi.org/10. 5194/tc-2017-201. in review

77. Overland JE, Francis JA, Hanna E, Wang M. The recent shift in early summer Arctic atmospheric circulation. Geophys Res Lett. 2012;39:L19804. https://doi.org/10.1029/2012GL053268.

78. Overland J, Francis JA, Hall R, Hanna E, Kim S-J, Vihma T. The melting arctic and midlatitude weather patterns: are they connected? J Clim. 2015;28:7917-32.

79. Overland JE, Dethloff K, Francis JA, Hall RJ, Hanna E, Kim S-J, et al. Nonlinear response of mid-latitude weather to the changing Arctic. Nat Clim Chang. 2016;6:992-9.

80. Overly TB, Hawley RL, Helm V, Morris EM, Chaudhary RN. Greenland annual accumulation along the EGIG line, 19592004, from ASIRAS airborne radar and neutron-probe density measurements. Cryosphere. 2016;10:1679-94. https://doi.org/10. 5194/tc-10-1679-2016.

81. Pfeffer WT, Arendt AA, Bliss A, Bolch T, Cogley JG, Gardner AS, et al. The Randolph Glacier Inventory (2014): a globally complete inventory of glaciers. J Glaciol. 2014;60 https://doi. org/10.3189/2014JoG13J176.

82. Poinar K, Joughi I, Lilien D, Brucker L, Kehrl L, Nowicki S. Drainage of southeast Greenland firn aquifer water through crevasses to the bed. Front Earth Sci. 2017;5 https://doi.org/10.3389/ feart.2017.00005.

83. Polashenski C, Courville Z, Benson C, Wagner A, Chen J, Wong $\mathrm{G}$, et al. Observations of pronounced Greenland ice sheet firn warming and implications for runoff production. Geophys Res Lett. 2014;41:4238-46. https://doi.org/10.1002/2014GL059806.

84. Polashenski CM, Dibb JE, Flanner MG, Chen JY, Courville ZR, Lai AM, et al. Neither dust nor black carbon causing apparent albedo decline in Greenland's dry snow zone; implications for MODIS C5 surface reflectance. 2015. doi:https://doi.org/10. 1002/2015GL065912.

85. Rennermalm AK, Smith LC, Chu VW, Box JE, Forster RR, van den Broeke MR, et al. Evidence of meltwater retention within the Greenland ice sheet. Cryosphere. 2013;7:1433-45. https://doi.org/ 10.5194/tc-7-1433-2013.
86. Rhoades AM, Huang X, Ullrich PA, Zarzycki CM. Characterizing Sierra Nevada snowpack using variable-resolution CESM. J Appl Meteorol Climatol. 2016;55:173-96.

87. Rignot E, Box JE, Burgess E, Hanna E. Mass balance of the Greenland ice sheet from 1958 to 2007. Geophys Res Lett. 2008;35:L20502. https://doi.org/10.1029/2008GL035417.

88. Ryan JC, Hubbard AL, Stibal M, Box JE. Attribution of Greenland's ablating ice surfaces on ice sheet albedo using unmanned aerial systems. Cryosphere Discuss. 2016 https://doi.org/ 10.5194/tc-2016-204

89. Selmes N, Murray T, James TD. Fast draining lakes on the Greenland ice sheet. Geophys Res Lett. 2011;38:L15501. https:/ doi.org/10.1029/2011GL047872.

90. Smeets CJPP, Kuipers Munneke P, van As D, van den Broeke MR, Boot W, Oerlemans J, et al. The K-transect in west Greenland: twenty-three years of weather station data, Arctic, Antarctic and Alpine Research. In Press. 2017.

91. Smith MW, Quincey DJ, Dixon T, Bingham RG, Carrivick JL, Irvine-Fynn TDL, et al. Aerodynamic roughness of glacial ice surfaces derived from high-resolution topographic data. J Geophys Res Earth Surf. 2016;121:748-66. https://doi.org/10. 1002/ 2015JF003759.

92. Steger CR, Reijmer CH, van den Broeke MR, Wever N, Forster RR, Koenig LS, et al. Firn meltwater retention on the Greenland ice sheet: a model comparison. Front Earth Sci. 2017;5 https://doi. org/10.3389/feart.2017.00003.

93. Stevens LA, Behn MD, McGuire JJ, Das SB, Joughin I, Herring T, et al. Greenland supraglacial lake drainages triggered by hydrologically induced basal slip. Nature. 2015;522:73-6.

94. Stibal M, Box JE, Cameron KA, Langen PL, Yallop ML, Mottram $\mathrm{RH}$, et al. Algae drive enhanced darkening of bare ice on the Greenland ice sheet. Geophys. Res. Lett. In press. 2017.

95. Stroeve JC, Box JE, Wang Z, Schaaf C, Barrett A. Re-evaluation of MODIS MCD43 Greenland albedo accuracy and trends. Remote Sens Environ. 2013;138:199-214. https://doi.org/10. 1016/j.rse.2013.07.023.

96. Tedesco M, Lüthje M, Steffen K, Steiner N, Fettweis X, Willis I, et al. Measurement and modeling of ablation of the bottom of supraglacial lakes in western Greenland. Geophys Res Lett. 2012;39:L02502. https://doi.org/10.1029/2011GL049882.

97. Tedesco M, Box JE, Cappelen J, Fausto RS, Fettweis X, Hansen $\mathrm{K}$, et al. Greenland ice sheet, [in "State of the Climate in 2015"]. Bull Am Meteorol Soc. 2016a;97:S173-226.

98. Tedesco M, Mote T, Fettweis X, Hanna E, Jeyaratnam J, Booth JF, et al. 2016: Arctic cut-off high drives the poleward shift of a new Greenland melting record. Nat Commun. 2016b; 7 https://doi.org/ 10.1038/ncomms11723.

99. Tedesco M, Doherty S, Fettweis X, Alexander P, Jeyaratnam J, Stroeve J. The darkening of the Greenland ice sheet: trends, drivers, and projections (1981-2100). Cryosphere. 2016c;10: 477-96. https://doi.org/10.5194/tc-10-477-2016.

100. Uppala SM, Kållberg PW, Simmons AJ, Andrae U, Bechtold VDC, Fiorino M, et al. The ERA-40 re-analysis. Q J R Meteorol Soc. 2005;131:2961-3012. https://doi.org/10.1256/qj.04.176.

101. Van Angelen JH, Lenaerts JTM, Lhermitte S, Fettweis X, Kuipers Munneke P, van den Broeke MR, et al. Sensitivity of Greenland ice sheet surface mass balance to surface albedo parameterization: a study with a regional climate model. Cryosphere. 2012;6:117586. https://doi.org/10.5194/tc-6-1175-2012.

102. Van As D, Andersen ML, Petersen D, Fettweis X, van Angelen $\mathrm{JH}$, Lenaerts JTM, et al. Increasing meltwater discharge from the Nuuk region of the Greenland ice sheet and implications for mass balance (1960-2012). J Glaciol. 2014;60(220):314-22. https://doi. org/10.3189/2014JoG13J065.

103. Van As D, Bech Mikkelsen A, Holtegaard Nielsen M, Box JE, Claesson Liljedahl L, Lindbäck K, et al. Hypsometric 
amplification and routing moderation of Greenland ice sheet meltwater release. Cryosphere. 2017;11:1371-86. https://doi.org/10. 5194/tc-11-1371-2017.

104. Van den Broeke MR, Enderlin EM, Howat IM, Kuipers Munneke P, Noël BPY, van de Berg WJ, et al. On the recent contribution of the Greenland ice sheet to sea level change. Cryosphere. 2016;10: 1933-46. https://doi.org/10.5194/tc-10-1933-2016.

105. Van den Hurk B, Kim H, Krinner G, Seneviratne SI, Derksen C, Oki T, et al. LS3MIP (v1.0) contribution to CMIP6: the Land Surface, Snow and Soil moisture Model Intercomparison Project-aims, setup and expected outcome. Geosci Model Dev. 2016;9:2809-32.

106. Van Kampenhout L, Lenaerts JTM, Lipscomb WH, Sacks WJ, Lawrence DM, Slater AG, et al. Improving the representation of polar snow and firn in the Community Earth System Model. J Adv Mod Earth Sys. In press. 2017.

107. Van Tricht K, Lhermitte S, Lenaerts JTM, Gorodetskaya IV, L'Ecuyer TS, Noël B, et al. Clouds enhance Greenland ice sheet meltwater runoff. Nat Commun. 2016;7 https://doi.org/10.1038/ ncomms 10266 .

108. Vaughan DG, Comiso JC, Allison I, Carrasco J, Kaser G, Kwok R, et al. Observations: cryosphere. In: Stocker TF, Qin D, Plattner GK, Tignor M, Allen SK, Boschung J, Nauels A, Xia Y, Bex V, Midgley PM, editors. Climate change 2013: the physical science basis. Contribution of working group I to the Fifth Assessment report of the Intergovernmental Panel on Climate Change. Cambridge: Cambridge University Press; 2013.

109. Vernon CL, Bamber JL, Box JE, van den Broeke MR, Fettweis X, Hanna E, et al. Surface mass balance model intercomparison for the Greenland ice sheet. Cryosphere. 2013;7:599-614. https://doi. org/10.5194/tc-7-599-2013.

110. Vizcaíno M, Lipscomb WH, Sacks WJ, van Angelen JH, Wouters B, van den Broeke MR. Greenland surface mass balance as simulated by the Community Earth System Model. Part I: model evaluation and 1850-2005 results. J Clim. 2013;26:7793-812. https://doi.org/10.1175/JCLI-D-12-00615.1.

111. Wang Y, Ding M, van Wessem JM, Schlosser E, Altnau S, van den Broeke MR, et al. A comparison of Antarctic ice sheet surface mass balance from atmospheric models and in situ observations. J Clim. 2016;29:5317-37. https://doi.org/10.1175/JCLI-D-15-0642.1.

112. Wilton DJ, Jowett A, Hanna E, Bigg GR, van den Broeke MR, Fettweis $\mathrm{X}$, et al. High resolution $(1 \mathrm{~km})$ positive degree-day modelling of Greenland ice sheet surface mass balance, 1870 2012 using reanalysis data. J Glaciol. 2016; https://doi.org/10. 1017/jog.2016.133.

113. Wouters N, Bamber JL, van den Broeke MR, Lenaerts JTM, Sasgen I. Limits in detecting acceleration of ice sheet mass loss due to climate variability. Nat Geosci. 2013;6 https://doi.org/10. 1038/ngeo1874. 